http://e-journal.stit-islamic-village.ac.id/index.php/JM2PI

\title{
Analisis Kreativitas Kegiatan Menggambar pada Anak Usia Dini
}

\author{
Umaria Husnu \\ Program Studi Pendidikan Islam Anak Usia Dini, STIT Islamic Village Tangerang \\ Email: Umariahusnu20@gmail.com
}

Received: September, 2020.

Published: November, 2020

Accepted: Oktober, 2020.

\begin{abstract}
In this study the researchers analyzed this title because of the low support from educators and parents in developing children's creativity, drawing is not the main priority in developing creativity, and the lack of children's ability to develop creativity drawing activities in early childhood. In analyzing the creativity of drawing in early childhood, it is hoped that educators and parents can find out more in understanding the importance of developing the creativity of drawing activities in early childhood. This research is a library research (library research) that uses primary data sources and secondary data, with data collection techniques: library, and accessing internet sites (Websites). The validity of the data uses method triangulation. Data analysis uses data reduction analysis techniques, data displays and drawing conclusions.
\end{abstract}

The results showed that drawing activities in early childhood can develop children's creativity. The process of drawing activities of children is able to create or combine ideas and ideas in divergent and thinking by providing motivation, supporting facilities for creativity, and freedom for children to explore their thinking abilities.

Keywords: creativity, activites drawing

\section{ABSTRAK}

Penelitian ini mengkaji tentang rendabnya dukungan dari pendidik dan orang tua dalam mengembangkan kreativitas anak, menggambar bukan prioritas utama dalam mengembangkean kreativitas, dan minimnya kemampuan anak dalam mengembangkan kreativitas kegiatan menggambar pada anak usia dini. Kreativitas kegiatan menggambar, berharap para pendidik maupun orang tua dapat mengetahui lebih dalam memahami pentingnya menstimulus kereativitas menggambar pada anak. Penelitian yang dilakukan yaitu (library research) yang menggunakan sumber data primer dan sekunder, dengan teknik pengumpulan data: kepustakaan, dan mengakses situs internet (Website). $V$ aliditas data yang digunakan yaitu triangulasi metode. Analisis data menggunakan teknik analisis reduksi data, data display dan penarikan simpulan. 
Hasil penelitian menunjukkan bahwa kegiatan menggambar mampu menstimulus kreativitas anak. Proses kegiatan menggambar anak. mampu menciptakan atau mengkombinasikan ide dan gagasan dalam berpikir divergen. Kegiatan menggambar dapat di lakukan dengan pemberian motivasi, fasilitas penunjang kreativitas, dan kebebasan kepada anak dalam mengeksplor kemampuan berpikimya.

Kata kunci: kreativitas, kegiatan menggambar

\section{PENDAHULUAN}

Pendidikan yang diberikan pada masa dini adalah pendidikan yang dimulai dari usia 0 sampai 6 tahun, masa ini adalah masa keemasan untuk mendapatkan stimulus yang baik dari luar terutama sejak dalam masa kandungan. Pendidikan merupakan suatu tindakan dalam membimbing anak dengan tujuan mengembangkan aspek perkembangannya. Pendidikan pada usia dini adalah masa yang tepat untuk memberikan stimulus yang baik bagi aspek perkembangan moral agama, kognitif, sosial emosional, fisik motorik, bahasa serta seni dan yang menjadi salah satu pengembangan potensi keterampilan seorang guru dalam menghasilkan sebuah kreativitas anak salah satunya melalui kegiatan menggambar.

"Berdasarkan Undang-Undang Republik Indonesia No.20 Tahun 2003 tentang Sistem Pendidikan Nasional, pendidikan anak usia dini adalah suatu upaya pembinaan yang ditujukan kepada anak sejak lahir sampai usia enam tahun yang dilakukan melalui pemberian rangsangan pendidikan untuk membantu pertumbuhan dan perkembangan jasmani dan rohani agar anak memiliki kesiapan dalam memasuki pendidikan lebih lanjut "(Helmawati, 2015:43)

Diantara aspek perkembangan anak yaitu seni. Mengembangkan kemampuan seni anak akan berpengaruh terhadap aktifitas fisik motorik anak. Kemampuan anak dalam berpikir kritis serta ketangkasan motorik halus anak dalam perkembangan seni sangat berpengaruh terhadap masa depan 
yang akan datang karena dipengaruhi oleh lingkungan yang akan mendukung kedua aspek tersebut.(Mayar et al., 2019)

Kreativitas dalam pendidikan sangat diperlukan oleh seorang anak, pada zaman saat ini penuh dengan persaingan baik dalam bidang pendidikan, teknologi, ekonomi dan sosial. Seperti tokoh dunia yang terkenal Thomas Alva Edison seorang penemu lampu pijar yang akhirnya menikmati dari proses berpikir kreatifnya mendapatkan kenikmatan atas karyanya, dengan kerja keras dan pantang menyerah.(Maulana \& Mayar, 2019:1141-1142)

"Maxim (1980) mengungkapkan, bahwa pada anak tertentu dapat menampilkan derajat kreativitas yang lebih tinggi dibanding anak lain, meski demikian harus dipahami bahwa tidak ada anak yang tidak memiliki kreativitas. Oleh sebab itu, seorang guru harus yakin bahwa anak-anak didik mereka semua kreatif, hanya bagaimana lingkungan merangsang kemunculan kreativitas mereka, dan seorang guru tidak menilai bahwa anak tidak bisa berkreativitas". (Maulana \& Mayar, 2019:1142)

Kreativitas yang dimiliki anak merupakan satu solusi motoriknya dan kemampuan anak dalam memecahkan suatu permasalahan, dapat memberikan kepuasan anak dalam meningkatkan kualitas hidupnya. Dengan kreativitas anak akan memiliki masa depan yang gemilang. Anak sebagai generasi penerus bangsa harus mempunyai kreativitas yang baik karena sejatinya anak adalah masa dimana dalam proses pembelajarannya membutuhkan pengembangan diri dalam meningkatkan kemampuankemampuan yang dimilikinya.

Kegiatan menggambar yang dirancang dengan sedemikian rupa dan merupakan suatu pendekatan sebagai alat ukur untuk melihat sejauh mana anak tersebut mengembangkan kreativitasnya juga sebagai penunjang yang cukup agar anak memiliki minat dan terinspirasi dalam menuangkan ideidenya di media menggambar yang merupakan salah satu kegiatan positif 
yang sudah di memiliki tolak ukur dalam menstimulus kreativitas dalam beberapa tahun terakhir dan dengan harapan semua anak menjadi anak yang kreatif dan memiliki ide-ide serta mampu memecahkan masalah sederhana di dalam kehidupannya untuk kelangsungan masa depannya nanti (Mayar et al., 2019:1367).

Disisi lain, kegiatan menggambar merupakan bagian dari aspek seni, salah satu tingkat pencapaian perkembangan anak yang perlu mendapatkan stimulasi sesuai dengan tahap perkembangannya. Kegiatan menggambar juga merupakan kegiatan bermain imajinasi serta sebuah tindakan seni yang ternyata, mampu dirangsang sejak dini, salah satunya dengan melalui kegiatan menggambar. Kegiatan yang dilakukan oleh anak dengan memberikan kebebasan ruang dan waktu, membuat anak menjadi senang. Adanya rasa senang akan mampu membuat anak melakukan sesuatu dengan melibatkan fisik dan mental. Menciptakan lingkungan yang membuat anak melakukan kegiatan secara rutin dan menjadi sebuah kebiasaan, merupakan suatu hal yang sangat fantastis. Dengan hal tersebut akan menciptakan anak yang kreativitasnya teruji serta memiliki efek samping yang positif dengan hasil karya yang mereka miliki .

Kegiatan menggambar tidak hanya kegiatan fisik saja yang dapat menghasilkan kreativitas, tetapi dengan adanya proses pembelajaran lainnya yang dapat mengembangkan kreativitas anak. Di zaman modern ini, seorang pendidik harus memiliki kreativitas yang tinggi baik dalam memberikan pembelajaran maupun mengembangkan seluruh potensi anak. Potensi yang dimiliki setiap anak tentunya berbeda-beda, maka peran guru dan orang tua dalam membantu kreativitas belajar anak yang dapat menentukan, apakah anak tersebut dapat berkembang kreativitasnya atau tidak. 
Kegelisahan yang terjadi dalam dunia pendidikan saat ini, rendahhnya kreativitas anak dalam kegiatan menggambar. Pada dasarnya kegiatan menggambar yang dilakukan anak, dapat menjadikan suatu peluang kesuksesan pada diri anak. Pendidikan anak usia dini berharap anak sudah diberikan pelatihan dalam mengembangkan potensi yang dimilikinya. Pada saat ini, masih terdapat pandangan yang kurang baik dari beberapa pihak dalam dunia pendidikan, baik guru maupun orang tua yang meremehkan akan pentingnya kegiatan menggambar yang dilakukan anak. Terjadinya sudut pandang tersebut, dikarenakan kurangnya pengetahuan akan pentingnya kegiatan menggambar, sehingga tidak semua pendidik memahami bagaimana tumbuhnya kreativitas anak melalui kegiatan menggambar.

\section{METODE}

Penelitian ini merupakan jenis penelitian library research yang menggunakan pendekatan analisis buku. Penelitian kepustakaan atau library research adalah salah satu jenis metode penelitian kualitatif. "Menurut Denzim \& Lincoln (1994) menyatakan bahwa penelitian kualitatif adalah penelitian yang menggunakan latar alamiah dengan maksud menafsirkan fenomena yang terjadi dan dilakukan dengan jalan melibatkan berbagai metode yang ada. penelitian kualitatif tidak menggunakan statistik, tetapi melalui pengumpulan data, analisis dengan pemahaman dari tujuan penelitian kualitatif adalah menjelaskan, meramalkan, dan mengontrol fenomena melalui pengumpulan data terfokus dan data numerik.(Anggito \& Setiawan, 2018). Penelitian kepustakaan adalah penelitian kualitatif, maka segenap prosedur yang dilakukan menggunakan penelitian kualitatif yang berlaku pada penelitian kepustakaan".(Amir Hamzah, 2019:7)

\section{HASIL}

Hasil penelitian menunjukkan bahwa kegiatan menggambar dapat memperkaya kreativitas anak. Proses kegiatan menggambar anak mampu menciptakan atau mengkombinasikan ide dan gagasan dalam berpikir divergen. Kegiatan menggambar dapat di lakukan dengan pemberian motivasi, fasilitas 
penunjang kreativitas, dan kebebasan kepada anak dalam mengeksplor kemampuan berpikirnya.

\section{PEMBAHASAN}

\section{Kreativitas Anak Usia Dini}

Anak merupakan pemberian Allah SWT, oleh karena itu sebagai orang tua bersyukur dengan apa yang Allah titipkan kepada hambanya sebagai bentuk amanah. Menjadikan anak sebagai wadah untuk memberikan teladan yang baik. Mewujudkan potensi yang secara naluriah telah ada dengan pendidikan yang sesuai dengan perkembangannya. Sebagaimana firman Allah SWT dalam surat Luqman ayat 12-13:

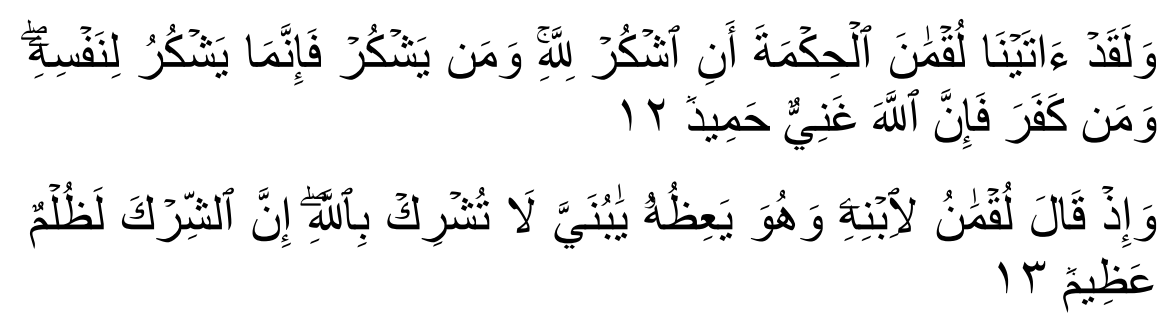

"Artinya: Dan sungguh, telah kami berikan hikmah kepada luqman, yaitu,'Bersyukurlah kepada Allah! Dan barangsiapa bersyukur kepada Allah, maka sesungguhnya dia bersyukur untuk dirinya sendiri, dan barangsiapa yang tidak bersyukur, maka sesungguhnya Allah Maha Kaya dan Maha Terpuji. Dan ingatlah ketika luqman berkata kepada anaknya, ketika dia memberi pelajaran kepada anaknya, "wahai anakku! Janganlah engkau mempersekutukan Allah, sesungguhnya mempersekutukan Allah adalah benar-benar kedzaliman yang besar”

Kreativitas merupakan sebuah potensi yang dimiliki seorang anak, dalam mengembangkan kemampuan yang ada dalam dirinya. Suatu bangsa dapat berkembang dengan maju membutuhkan generasi yang kreatif. 
Pengembangan kreativitas, merupakan sebuah pengetahuan yang terus berkembang dinamis, sesuai dengan zamannya dan ilmu teknologinya.

"Menurut Hurclock ia menjelaskan bahwa kreativitas merupakan proses mental yang dilakukan untuk menghasilkan sesuatu yang baru, berbeda, dan orisinil". Kemudian menurut Maslow dalam Schultz mengatakan bahwa kreativitas sama halnya dengan suatu proses menciptakan dari proses berimajinasi anak, dengan cara yang tak terduga, dan dapat melihat secara langsung pada hal-hal yang bersifat asertif." (Mulyani, 2019:8).

Kreativitas termasuk alat untuk membuat generasi yang unggul dan mampu membuat kemajuan perkembangan zaman. Perkembangan kreativitas perlu mendapat perhatian pada masa usia dini. Kreativitas dapat diberikan sejak anak masih usia dini, ketika masih dalam kandungan anak. Pemberian stimulus sejak di dalam kandungan, merupakan bagian edukasi anak sejak nol bulan. Edukasi sejak anak dalam kandungan akan mampu menstimulus perkembangan kreativitas anak, yang kelak akan menjadi seorang anak penerus generasi bangsa yang mampu hidup mandiri dan berprestasi dibidangnya.

Pada dasarnya seorang anak terlahir dengan memiliki potensi kreativitas dalam dirinya, sebagaimana firman Allah SWT dalam Al-Quran Surah AnNahl ayat 78 :

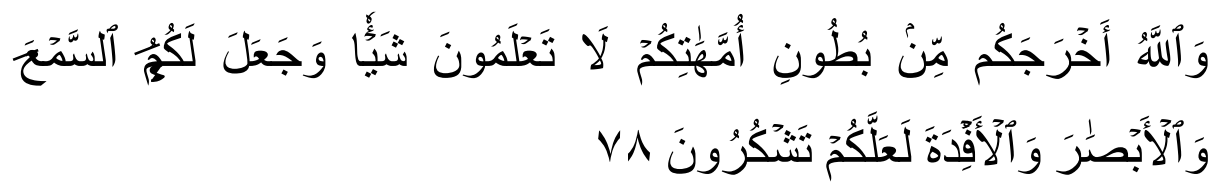

Artinya: "Dan Allah mengeluarkan kamu dari perut ibumu dalam keadaan tidak mengetahui sesuatu pun, dan Dia memberimu pendengaran, pengelihatan dan hati nurani, agar kamu bersyukur? 
Sebagaimana firman Allah swt, di atas memberi gambaran bahwa setiap manusia terlahir ke dunia tidak dengan membawa apa-apa baik harta, jabatan maupun kekayaan. Kecuali manusia hanya membawa potensi yang telah diberikanAllah swt kepada . Tidak ada anak yang tidak memiliki potensi, jika potensi tersebut diarahkan dan terstimulus dengan baik, maka anak akan menjadi manusia yang memiliki kreativitas.

Dikutip dari buku Pengembangan Kreativitas Anak Usia Dini karangan Masganti Sit, dkk menjelaskan bahwa:

"Dalam pandangan islam, Allah telah meniupkan roh ke dalam diri manuisa. Oleh karena itu, di dalam diri manusia memiliki sifat-sifat ilahiyah walaupun dalam kadar yang rendah. Seperti di ketahui bahwa Allah memiliki 99 sifat yang disebut asmaul husna. Dari 99 sifat tersebut setidaknya ada tiga yang berkaitan dengan kreativitas, yaitu: al-khaliq (maha pencipta), almushawwir (maha memberi bentuk), al-mubdi (yang memulai)". (Masganti Sit, 2016:38).

Berdasarkan penjelasan di atas bahwa Allah memberikan potensi kepada manusia. Allah yang maha mencipta bahwa sesungguhnya semua yang terjadi atas kreativitas manusia pada awalnya adalah merupakan pemberian Allah yang maha mencipta (Khaliq) Allah yang maha menciptakan sebelum manusia dapat membuat sesuatu, adapaun Allah memberi bentuk (almushawnir ) bahwa manusia menciptakan sesuatu dengan bentuknya dari proses kreativitas merupakan sifat Allah yang ada di dalam roh manusia, sedangkan (al-mubdi) bahwa Allah yang memulai segala yang ada di muka bumi ini dan kreativitas yang dimiliki manusia hanya perantara dalam mengembangkan dan memajukan kehidupannya.

Tanpa kreativitas, kehidupan manusia tidak akan berkembang. Jika awalnya manusia tidak dapat menciptakan sesuatu yang baru, maka hal tersebut tidak akan terjadi. Kreativitas merupakan nikmat pemberian Allah 
yang luar biasa, dengan kreativitas manusia bisa membangun rumah, gedung, dan pesawat. Hal tersebut menjadikan manusia sebagai makhluk yang berpikir kreatif. (Masganti Sit, 2016:38)

Utami Munandar (1999: 26) terdapat beberapa unsur-unsur yang dapat menunjang kreativitas anak, sebagai berikut:

1. "Pribadi (person) adalah ungkapan keunikan individu dalam interaksi dengan lingkungan dari pribadi yang unik inilah diharapkan timbul ide-ide baru dan produk yang inovatif.

2. Proses (process) adalah untuk mengembangkan kreativitas siswa, ia perlu diberi kesempatan untuk bersibuk secara aktif, untuk itu yang penting adalah memberi kebebasan kepada siswa untuk mengekspresikan dirinya secara kreatif dengan kegiatan-kegiatan yang mengasah kemampuan berpikirnya.

3. Pendorong (press) adalah dalam mewujudkan bakat kreatif siswa diperlukan dorongan dan dukungan dalam bentuk motivasi dari lingkungan (motivasi eksternal) yang berupa apresiasi, dukungan, pemberian penghargaan, pujian, insentif dan dorongan dari dalam diri siswa sendiri (motivasi internal) untuk menghasilkan sesuatu.

4. Produk (product) adalah aktivitas seseorang dalam menciptakan produk kreatif, yang di dukung dengan kondisi lingkungan dan kondisi pribadi."(Handayani \& Somantri, 2019)

Adapun ciri-ciri aptitude (kreatif) yang berhubungan dengan berpikir divergen yaitu:

1. "Keterampilan berpikir lancar yaitu anak mampu menciptakan gagasan-gagasan, jawaban, dan dapat menyelesaikan masalah atau pertanyaan.

2. Keterampilan berpikir luwes yaitu kemampuan yang dimiliki anak untuk dapat menghasilan gagasan, jawaban atau pertanyaan yang bervariasi, serta dapat melihat suatu masalah dari sudut pandang yang berbeda-beda.

3. Keterampilan berpikir orisinal yaitu kemampuan yang melahirkan sesuatu yang asli dan unik.

4. Keterampilan memperinci (mengelaborasi) yaitu kemampuan mengembangkan, memperkaya atau memperinci secara detail dari suatu gagasan sehingga menjadi lebih menarik. 
5. Keterampilan menilai yaitu kemampuan anak dalam menentukan penilaian sendiri terhadap suatu pertanyaan, rencana atau sebuah tindakan itu bijaksana atau tidak."(Mulyani, 2019:11)

Permasalahan yang menyebabkan rendahnya kreativitas anak di Indonesia yang menghambat potensi kreatif anak, sebagai berikut:

1. Hambatan diri sendiri

Berdasarkan sudut psikologi perilaku individu yang menghambat kreativitas: perilaku sehari-hari yang membuat diri sendiri timbul rasa malas, kurangnya berusaha, berpikir pasif, tidak berani dalam mengambil keputusan, dan tidak mau berkembang.

2. Pola asuh yang diberikan

Penerapan bagaiaman cara mengurus kehidupan anak jika tidak tepat dilakukan orang tua terhadap anak yang diberikan kepada anak akan berpengaruh besar terhadap perkembangan potensi kreatif anak. Memberikan kebebasan kepada anak akan menjadikan anak memiliki sikap saling menghargai, menghormati, dan mampu mendengan pendapat keluarganya.

\section{Pendidikan}

Sistem pendidikan di Indonesia lebih mengarah kepada upaya pembentukan manusia untuk menjadi pintar. Selanjutnya Utami Munandar memaparkan kondisi di sekolah yaitu sikap guru, belajar dengan hafalan mekanis, kegagalan sehingga berdampak pada motivasi instrik dan kreativitas, dan tekanan akan membawa pengaruh baik di rumah, sekolah ataupun lingkungan. Karena dengan memberikan kebebasan kepada anak, ia akan menjadi dirinya sendiri.(Yeni Rachmawati, 2010:7-9) 
Menurut (Rachmawati dan kurniati, 2010). Kreativitas dan kecerdasan sangat erat hubungannya diantara keduanya walaupun tidak ada hubungannya secara mutlak. Seseorang yang kreatif dipastikan memiliki kecerdasan, akan tetapi seseorang yang cerdas tidak selalu kreatif. Hurlock berpendapat bahwa terciptanya sebuah karya yang kreatif membutuhkan lebih dari sekedar kecerdasan. Misalnya, beberapa anak yang pandai pada bidang akademisnya , akan tetapi, sebagian anak tersebut tidak pandai dalam berpikir kreatif. Karena tidak hanya sekedar "memberikan yang diinginkan oleh guru" (Hurlock, 1978). Hubungan antara kecerdasan dan kreativitas sebagian besar bergantung pada faktor di luar kreativitas dan kecerdasan itu sendiri (Mulyani, 2019:15-16).

\section{Menggambar}

Kegiatan menggambar juga merupakan proses yang dilakukan seseorang untuk membuat gambar dengan cara menggoreskan benda-benda tajam seperti pensil atau pena pada bidang datar misalnya permukaan papan tulis, kertas, atau dinding (Depdiknas Dirjen Dikti, 2005 : 15) kegiatan menggambar kegiatan yang tidak membosankan bagi anak dan akan ada ide yang anak tuangkan kedalam gambar dengan permainan tekstur, warna dan pola serta objek gambar.

Dikutip dari Jurnal Mutiara Pendidikan Indonesia yang berjudul "Pengaruh Metode Bercerita Terhadap Kreativitas kegiatan menggambar Anak Usia 5-6 Tahun" karangan Meylina Girsang dan Jernih Samosir, mengatakan bahwa:

"Menurut Anik Pamilu (2007:69) menjelaskan bahwa kegiatan menggambar merupakan sarana yang tepat dan sesuai untuk anak usia Taman Kanak-kanak dalam rangka mengaktualisasikan, mengeskpresikan diri, dan membantu anak untuk mengembangkan serta meningkatkan imajinasi dan 
kreativitasnya melalui kegiatan mengeksplorasi warna, tekstur, dan bentuk dengan media kegiatan menggambar yang dituangkan sesuka hatinya, bebas, spontan, kreatif, unik, dan bersifat individual".(Girsang \& Samosir, 2019)

Mengenai penjelasan di atas bahwa kegiatan menggambar merupakan kegiatan yang dapat mengembangkan potensi anak dalam. Dalam kegiatan menggambar anak akan bermain warna, tekstur, dan gambar sesuai dengan imajinasinya. Hal tersebut akan meningkatkan kreativitas anak.

Dalam proses pembuatan gambar yang dilakukan anak-anak, akan mengalami berbagai macam tipe yang dihasilkan, sebagai berikut:

1. Tipe Komik, yaitu kemampuan anak dalam memunculkan tulisan dalam gambar, dengan tujuan ingin mengutarakan pendapat tentang sesuatu hal dari pengalamannya. Contohnya, anak membuat gambar mobil yang ada di jalan raya kemudia dipadukan dengan tulisan-tulisan sehingga seperti komik

2. Tipe Naturalistik, yaitu hampir sama dengan tipe realistik. Anak akan kegiatan menggambar pemandangan yang sesuai dengan apa yang sebenarnya.

3. Kegiatan menggambar cerita kepahlawanan, yaitu setiap anak memiliki kesenangan dalam kegiatan menggambar tokoh kepahlawanan. Hal tersebut di dasari oleh faktor luar contohnya melihat dan membaca tokoh-tokoh komik atau video dan televise.

4. Bertumpu pada garis dasar, yaitu pandang spasial artinya suatu objek akan dipandang satu sisi, walaupun pada dasarnya seluruh gambar akan ditampilkan yang ditandai dengan objek berdiri. Contohnya pohon kelapa berdiri, bangku berdiri di atas lantai dan orang yang berdiri. Semuanya dipersepsikan dengan sendiri 
5. Transparansi (X-Ray), yaitu ciri gambar yang tembus pandang dan sering muncul seiring perkembangan mental anak yaitu pikiran dan perasannya.

6. Tipe susunan bebas, dapat disebut dengan tipe anorganik yaitu susunan yang diletakkan pada gambar dengan tanpa mengenal urutan ceritanya.(Sukardi, 2018:43-47)

Kemampuan kegiatan menggambar pada anak tentu akan menghasilkan output yang baik untuk diri anak jika kemampuan yang dimiliki anak diberikan stimulus yang baik. Adapun manfaat dari kegiatan menggambar bagi seorang anak yaitu:

1. Kegiatan menggambar sebagai Alat Bercerita

Kegiatan menggambar melatih kemampuan anak dalam berpendapat, dari yang nyata sampai symbol yang bagian dari proses berimajinasi yang tidak dapat diungkapkan.

2. Kegiatan menggambar sebagai Media Mencurahkan Perasaan

Menurut Soesatyo (1994) mengemukakan sebagai berikut:

"Anak kegiatan menggambar adalah menceritakan, mengungkapkan (mengekspresikan) sesuatu yang ada pada dirinya secara intuitif dan spontan lewat media gambar, maka karya lukis anak-anak adalah seni meskupun tidak disamakan dengan karya lukis orang dewasa, namun adanya syarat-syarat kesenian-lukisan telah terpenuhi dengan adanya teknik artistik, dan ekspresi."

Kegiatan menggambar bagi anak bukan saja merupakan kegiatan yang hanya bertumpu pada warna. Akan tetapi, kegiatan menggambar dapat menjadikan anak lebih luwes dalam mengutarakan pendapat.

3. Kegiatan menggambar sebagai Alat Bermain 
kegiatan menggambar melatih anak untuk berimajinasi secara universal. Imajinasi merupakan bagian dari dunia fantasi anak yang sering kali aneh untuk dilihat yang sederhana yang berada di sekitar lingkungan anak.

4. Kegiatan Menggambar Melatih Ingatan

Peristiwa atau kejadian yang telah dialami anak akan menjadi sebuah gagasan untuk anak mengungkapkan hal tersebut ke dalam bentuk gambar. Kejadian yang membuat kenangan akan disimbolkan dan diungkapkan dalam bentuk yang sangat spesifik. Hal ini dapat melatih ingatan anak

5. Kegiatan Menggambar Mampu Melatih Berpikir Komprehensif (Menyeluruh)

Ketika anak berpikir ingin menuangkan seluruh pengalaman dalam bentuk gambar(total narratives), yaitu bercerita tentang sesuatu yang baru ia lihat kemudian ia gambar dan gambar tersebut dihubungkan dengan cerita-cerita yang telah ia dengar sebelumnya.

6. Kegiatan Menggambar sebagai Ungkapan Perasaan

Kegiatan menggambar dapat menjadikan anak untuk meminimalisirkan spontanitas dan mengarahkan untuk mengajarkan cara berbicara.

7. Menggambar Melatih Keseimbangan

Pikiran dan perasaan yang dimiliki seorang anak pada dasarnya masih menjadi satu. Menurut Susanto (1956) menjelaskan bahwa usia 3-5 tahun pikiran dan perasaan anak masih menyatu dengan apa yang mereka bayangkan.

8. Kegiatan menggambar Melatih Kreativitas Anak Seorang anak terkadang dalam mencari perhatian pendidik maupun sekitarnya dengan menggunakan berbagai cara, misalnya: 
membuat sesuatu yang berbeda dari yang lainnya. Anak akan membuat gambar yang berbeda dari yang pernah sudah dibuat. Maka, muncul lah gagasan-gagasan mencipta karya-karya rupa, termasuk kegiatan menggambar.

9. Kegiatan menggambar Mampu Melatih Konsentrasi.

Kegiatan menggambar merupakan hasil kegiatan pengamatan terhadap media yang ada di sekitarnya. Oleh karenanya, pembelajaran seni rupa termasuk kegiatan menggambar dapat melatih ketelitian pengamatan anak dalam mengamati lingkungan sekitar (Sukardi, 2018:10-11).

Dalam proses kegiatan menggambar, anak akan menemukan hal-hal yang kemungkinan tidak pernah terluapkan sebelumnya. Mengapa demikian, karena hal tersebut merupakan kemampuan anak dalam daya cipta yang baru atau dari pengalaman yang telah dilihat sebelumnya. Anak yang kreatif Berikut kegiatan menggambar anak usia 2 sampai 6 tahun dengan Karakteristik yang berbeda-beda.

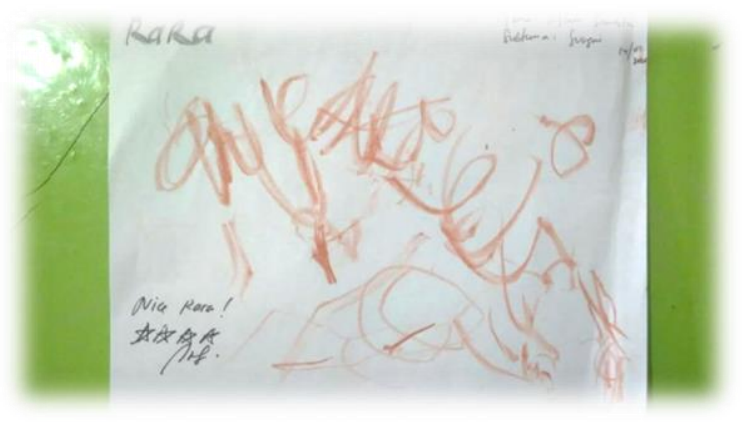

\section{Gambar 4.1}

Contoh gambar anak usia 2 tahun

Berdasarkan gambar 4.1 di atas bahwa dari coretan tersebut anak belum mampu memberikan tujuan apa yang ingin digambarkan. Goresan tersebut 
belum beraturan. Akan tetapi, dari tahap usia perkembangan gambar anak akan menunjukan gambar yang lebih lengkap.

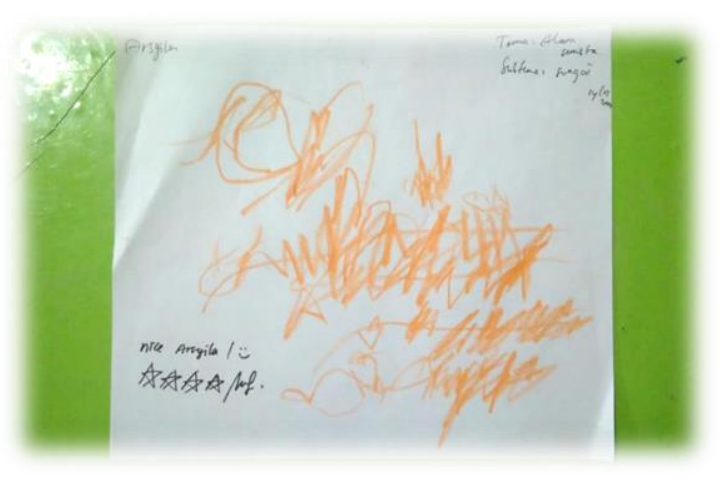

Gambar 4.2

Contoh gambar anak usia 3 tahun

Berdasarkan gambar 4.2 di atas bahwa anak usia 3 tahun dari garis yang terputus-putus akhirnya dapat terbentuk menjadi garisan yang bulat. Hal tersebutanak dapat mengkoordinasikan lengan dalam menggerakan tangannya secara keseluruhan. Sesuai dengan tahapan periodisasi gambar anak akan mengalami perubahan menjadi garis lurus membentuk bulan, matahari, atau bola.

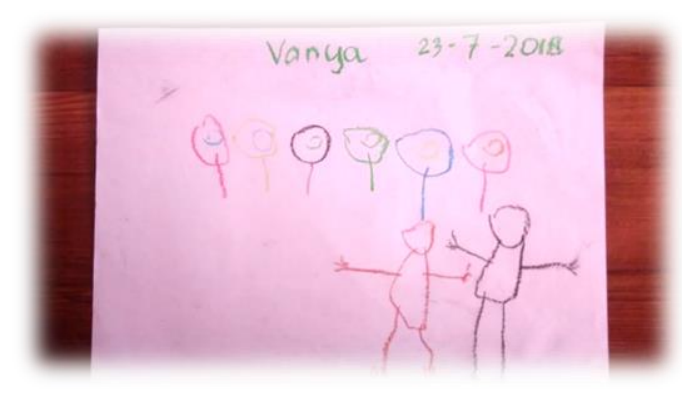

Gambar 4.3

Contoh Gambar Anak Usia 4 Tahun

JM2PI: Jurnal Mediakarya Mahasiswa Pendidikan Islam 
Berdasarkan perkembangan seni gambar anak pada gambar 4.3 dapat dinyatakan bahwa gambar di atas merupakan proses perkembangan kegiatan menggambar bentuk manusia. Anak akan menyadari bahwa gambar di atas sudah dapat dibaca oleh orang lain, walaupun gambarnya masih belum terlihat jelas. Karena anak masih suka mengekspresikan ide dan gagsannya secara spontan. Namun, pada suatu saat nanti anak akan mampu memberi judul dengan tetap dan sesuai.

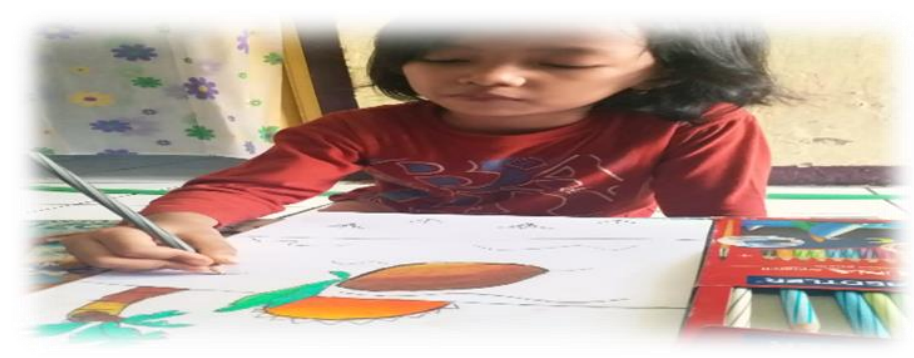

\section{Gambar 4.5}

Contoh Kegiatan menggambar Bebas Anak Usia 5 Tahun

Berdasarkan gambar 4.5 di atas, menunjukan bahwa anak dapat berpikir kreatif, anak fokus terhadap apa yang sedang digambar. Goresan-goresan yang dibuat dan diwarnai merupakan bentuk kongkrit. Memadukan warna menjadi sebuah warna gradasi merupakan bagian dari estetika gambar. Lingkungan keluarga yang mendukung akan mampu mengembangkan potensi kreativitas anak dalam kegiatan menggambar. Memberikan fasilitas penunjang dapat membuat anak merasa dihargai. 


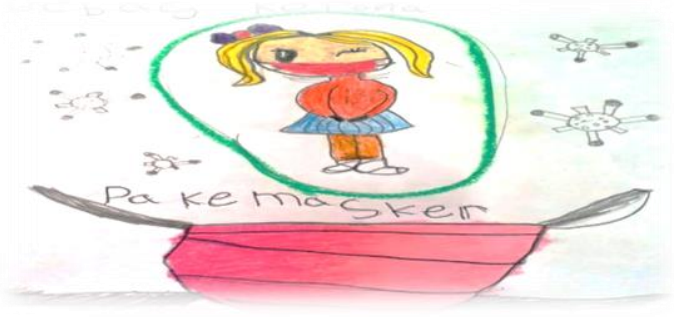

Gambar 4.6

Contoh Kegiatan menggambar bebas anak Usia 6 Tahun

Berdasarkan gambar 4.6. Hal tersebut dapat menunjukkan bahwa anak usia 5 tahun mampu kegiatan menggambar dengan berpikir kongkrit. Sesuai dengan kejadian yang sedang dialami, ia mampu mengkombinasikan 2 gagasan yang pernah ia lihat ke dalam gambar. Dari Karakteristik gambar anak usia 5-6 tahun sudah mampu membuat figur manusia secara lengkap dan dapat berpikir secara divergen. Hal tersebut menunjukkan bahwa terdapat kreativitas dalam kegiatan menggambar ada dalam gambar di atas.

\section{SIMPULAN}

Kreativitas anak dapat ditandai dengan adanya anak berpikir kreatif, dapat menghubungkan dua gagasan yang bersifat orisinil. Kegiatan menggambar pada anak usia dini adalah bagian dari perkembangan seni rupa anak, yang pada setiap individu anak memiliki kreativitasnya masing-masing. Kegiatan menggambar berfungsi sebagai kegiatan yang menyenangkan bagi anak jika diberikan fasilitas dan motivasi kepada anak. Dengan kegiatan menggambar anak dapat mencoret, menggoreskan, dan membuat bentuk yang akan dieksplor dengan bemain warna. Kreativitas kegiatan menggambar pada merupakan sarana dalam mengembangkan segala potensi diri anak, dengan kegiatan menggambar anak akan mampu mengembangkan kreatifitas dirinya dengan menghubungkan gagasan-gagasannya yang tertuang lewat 
aktivitas seni. Perkembangan tersebut merupakan bagian dari perkembangan daya berpikir anak dalam menciptakan atau mengkombinasikan sesuatu menjadi karya.

\section{REFERENSI}

Amir Hamzah. (2019). Metode Penelitian Kepustakaan (1st Ed.). Literasi Nusantara.

Anggito, A., \& Setiawan, J. (2018). Metodologi Penelitian Kualitatif. CV Jejak (Jejak Publisher).

Depdiknas Dirjen Dikti. (2005). Pengembangan Kreativitas Seni Rupa Anak TK. Departemen Pendidikan Nasional.

Girsang, M. L., \& Samosir, J. (2019). Pengaruh Metode Bercerita Terhadap Kreativitas Menggambar Anak Usia 5-6 Tahun. Jurnal Mutiara Pendidikan Indonesia, 4(2), 39-48.

Handayani, W., \& Somantri, E. B. (2019). Peningkatan Kreativitas Anak Usia 5-6 Tahun Melalui Kegiatan Kolase Di Taman Kanak-Kanak Mujahidin 1 Pontianak. Jurnal Edukasi Pendidikan Anak Usia Dini, 5(2).

Helmawati. (2015). Mengenal Dan Memahami PAUD (P. Latifah (Ed.); 1st Ed.). PT Remaja Rosdakarya.

Masganti Sit, Dkk. (2016). Buku Pengembangan Kreativitas Anak Usia Dini (Teori Dan Praktik). Perdana Publishing.

Maulana, I., \& Mayar, F. (2019). Pengembangkan Kreativitas Anak Usia Dini

Di Era Revolusi 4.0. Jurnal Pendidikan Tambusai, 3(5), 1141-1149.

Mayar, F., Husin, S. H., \& Sari, K. (2019). Peningkatan Kemampuan Kreatifitas Anak Melalui Kegiatan Menggambar Bebas Setiap Hari Di Taman Kanak-Kanak Darussalam Gadut. Jurnal Pendidikan Tambusai, 3(6), 1365-1373.

Mulyani, N. (2019). Mengembangkan Kreativitas Anak Usia Dini (N. N. M (ed.); 1st ed.). Pt Remaja Rosdakarya.

Sukardi, H. P. dan E. (2018). Seni Keterampilan Anak (20th ed.). Universitas Terbuka.

Yeni Rachmawati, E. K. (2010). Strategi Pengembangan Kreativitas Pada Anak Usia Taman Kanak-Kanak (cetakan pe). Kencana. 